\title{
Cultural Tourism as a Support of Local Content Learning in Gorontalo Regency
}

\author{
Moh. Karmin Baruadi (Corresponding Author) \\ Faculty of Letters and Culture, Universitas Negeri Gorontalo \\ J1. Jend. Sudirman, No. 6 Kota Gorontalo, Indonesia \\ E-mail:kbaruadi@gmail.com
}

Fory Armin Naway

Faculty of Education, Universitas Negeri Gorontalo

Jl. Jend. Sudirman, No. 6 Kota Gorontalo, Indonesia

Novriyanto Napu

Faculty of Letters and Culture, Universitas Negeri Gorontalo

Jl. Jend. Sudirman, No. 6 Kota Gorontalo, Indonesia

Sunarty Eraku

Faculty of Mathematics and Science, Universitas Negeri Gorontalo

Jl. Jend. Sudirman, No. 6 Kota Gorontalo, Indonesia

Syahrizal Koem

Faculty of Mathematics and Science, Universitas Negeri Gorontalo

Jl. Jend. Sudirman, No. 6 Kota Gorontalo, Indonesia

Received: September 5, 2018

doi: 10.5296/jsss.v6i1.13590
Accepted: October 2, 2018 Published: October 4, 2018

URL: http://doi.org/10.5296/jsss.v6i1.13590 


\section{Abstract}

As a region with abundant tourism destinations, Gorontalo regency is rich of cultural diversity as a potential support to enhance the region's tourism sector, one of which is the community's traditional culture. That being mentioned, it is crucial to implement professionalism in tourism asset management, particularly in optimization of ecological and cultural-based tourism object planning and arrangement. Additionally, it is essential to take into consideration of tourism object preservation and effective management in order to prevent negative impacts on ecological and socio-cultural environment. This study intends to identify the cultural tourism potential as a means to support local content learning in Gorontalo regency. The data were collected by survey, field observation, and interview. Moreover, Geographical Information System (GIS) was employed to identify cultural tourism destinations in the area and folklore analysis to provide descriptive elaboration of the sites. The result elaborates eight potential cultural tourism sites as a support of local content learning in Gorontalo regency, i.e. Huntu lo Bohu (Pentadio Resort), Fort van Tangale Monument, Limboto Lake Historical Site, Soekarno Amphibious Aircraft Landing Monument, Bubohu Kingdom Site, Sacred Tomb of Baruwadi, Taluhu Barakati Hot Spring, and Bantayo Poboide Traditional House. From the findings, the study generates information in form of background story of the tourism site, which is closely related to the local community's folklore that develops throughout the time. The folklore, as an element of local culture, is recommended to be implemented in local content learning to the community as an act of preserving Gorontalo's local wisdom.

Keywords: Folklore, Local content, Culture tourism

\section{Introduction}

Gorontalo regency is featured with tourism destinations which embody local cultural values, in which the sites are invaluable assets to the tourism sector. By that, a professional management of tourism assets is essential to be implemented, particularly in planning and arrangement phase by referring to ecological and cultural aspects as an optimization of the assets. Moreover, as a means of preservation, an effective asset management is critical to implement to avoid negative impacts on the ecological and socio-cultural aspects of the community.

A tourism destination is potential to be developed in different ways. The number of potencies within a tourism destination provides various alternatives for development and optimization. Soekadijo (2000) argues that tourism assets are potential to be developed into attractions within the site where a potential asset is found (in situ), or outside the original site (ex situ). Some potential attractions developed by in situ ways are candi (ancient temple) and hot spring; while park, zoo, and museum are example of potential attractions developed by ex situ ways.

Correia et al. (2011) state that local culture is one of attracting factors for tourists to visit certain attractions. With that being said, culture tourism is considered as an effective alternative in bridging various concepts of tourism study and in promoting holistic, flexible, 
and reflective perspective on tourism sector (Canavan, 2016). Moreover, Correia (2011) adds that cultural aspects of a destination play important role in attracting tourists. By that, cultural tourism development is considered essential to implement as an effort of creating sustainable tourism environment. Moreover, Qian (2016) argues that one of significant factors leading to sustainable tourism is by engaging local cultural values in tourism development.

Aside from economical means, development of local wisdom-based cultural tourism is essential for local content learning; this is to implant the community with tourism competence that embodies local values and potentials. Local content learning is part of curriculum structure and content as an element of national curriculum standard. It is a form of implementation of local-based education within each region relevant to the region's background and context, Moreover, the existence of local content education complies with and supports the national curriculum as an effort of enhancing national education quality. With that being said, the study aims to identify the cultural tourism potentials in Gorontalo regency to support local content education in the region.

\section{Research Method and Data}

The research employed Geographical Information System and folklore approach. Moreover, the data were obtained by field survey and interview; and analyzed descriptively by folklore approach in order to provide elaboration of cultural tourism potential in the research site. The research generated data involving cultural elaboration of folklore and the local community's competence of cultural tourism potentials, and folklore analysis of background history of tourism destinations in the research site.

\section{Findings and Discussion}

Taking place in the middle of Gorontalo province, Gorontalo regency is geographically located at $0^{\circ} 30^{\prime}-00^{\circ} 54^{\prime}$ North Latitude and $122^{\circ} 07^{\prime}-123^{\circ} 44^{\prime}$ East Longitude. The GIS result highlights eight potential cultural tourism sites as a support of local content learning in Gorontalo regency, i.e. Limboto Lake Historical Site, Bantayo Poboide Traditional House, Fort van Tangale Monument, Huntu lo Bohu (Pentadio Resort), Taluhu Barakati Hot Spring, Soekarno Amphibious Aircraft Landing Monument, Bubohu Kingdom Site, and Sacred Tomb of Baruwadi. The following Figure 1 displays cultural tourism map of Gorontalo regency. 


\section{Macrothink}

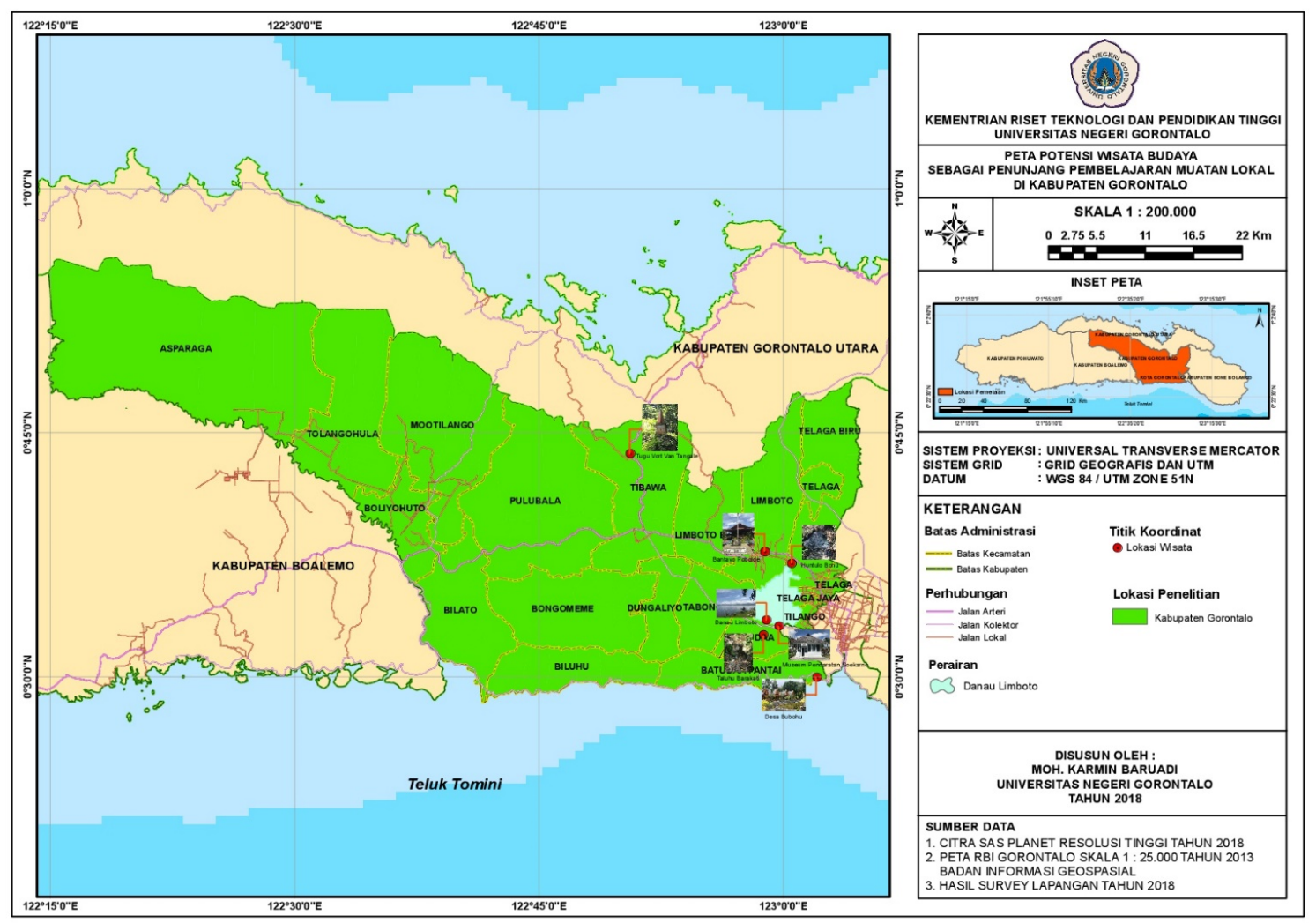

Figure 1. Cultural tourism map of Gorontalo regency

\subsection{Limboto Lake}

Limboto lake is located at $\left(122^{\circ} 42^{\prime} 0.24^{\prime \prime}-123^{\circ} 03^{\prime} 1.17^{\prime \prime} \mathrm{E}\right.$ longitude and $00^{\circ} 30^{\prime} 2.035^{\prime \prime}-$ $00^{\circ} 47^{\prime} 0.49^{\prime \prime} \mathrm{N}$ latitude) $0^{\circ} 35^{\prime} 0 \mathrm{~N}$ latitude $122^{\circ} 58^{\prime} 0^{\prime \prime} \mathrm{E}$ longitude / $0,58333^{\circ} \mathrm{N}$ latitude and $122,96667^{\circ} \mathrm{E}$ longitude/ Approximately $30 \%$ of the lake area is included in the administrative region of Gorontalo city, and the rest $70 \%$ is included in Gorontalo regency. Aside from its function as the community's main support of livelihood, Limboto lake is praised by the locals as a tourist destinations with beautiful panorama, particularly if observed from hilltops nearby. Providing support to the community's livelihood over the years, Limboto lake is considered as an ecotourism attraction with ecological and cultural features.

The folklore of the lake tells a story of a man descending from the sky; he is described as a young, mighty, and handsome man. The man's name is Jilumoto, literally means an incarnating entity that comes down to the world. Jilumoto then saw the angels bathe at Tupalo and hid one of the angels' wings. Eventually, the wings belong to Mbu'i Bungale, the oldest angel in the group. Got left behind by her sisters, Mbu'i Bungale then met Jilumoto and accepted Jilumoto's proposal to be his wife. The couple then decided to inhabit the earth and seek for fertile land to settle and make living. They discovered a hill they find suitable to settle and named it Huntu lo Ti'opo or cotton hill; then decided to build themselves a home and grow crops with plants for food. At one day, the couple saw five fruit-shaped things floating on a lake. They grasped, pinched, and smelled the fruit, only to discover that the fruit 
smelled fresh and fragrant, similar to the scent of lime they have in their origin place. The fruit is called limu tutu in Gorontalo language. By that, the lake is addressed as bulalo lo limu o tutu, literally means lake of lime truly from heavens. Over the years, the lake is more known as Bulalo lo Limutu. Drawing the red line between the folktale and local culture, it illustrates that the name 'Limboto' lake is originated from the lime fruit in the folktale. Moreover, in one of Gorontalo culture, lime is used in a ceremony for female circumcision, or lihu lo limu ceremony, literally translates to lime bathe. The ceremony is held to bathe a young female with mixture of water, lime, and seven herbs, which means seven characteristics to be removed from her personality during her growth.

\subsection{Bantayo Poboide Traditional House}

Bantayo Poboide Traditional House is located at $00^{\circ} 37^{\prime} 41,1^{\prime \prime} \mathrm{N}$ latitude and $122^{\circ} 58^{\prime}$, 51,1" E longitude. It is administratively included in the region of Kayu Bulan sub-district, Limboto district, Gorontalo regency. The name Bantayo Poboide derived from the word bantayo which means ward or hall, and poboide which means discuss. Physically, the traditional house takes form of a hall where local people gather to discuss an agenda. Otherwise, the name Bantayo Poboide can be defined as an governmental legislature in the kingdom era (equivalent to current legislative office). Therefore, Bantayo Poboide is a hall where organized legislative members gather to discuss issues about the kingdom, in which the legislature is above the king, possesses legal power, be independent, not related into any political bodies, works solely for the sake of the state's welfare, and nurture morality within the leader and the state's citizens in accordance with customary law and the Shari'a. The Bantayo Poboide implements kinship governmental system, which consists of three factions, i.e. Wombu and Dile that take control of the government; Tiyombu, consisting of the Baate mandated as customary power holders; and Tilo Tiyamoi faction, consisting of the society's representatives. The three factions in the governmental system originates from the local philosophy of Datahu lo Huntu Hu'idu which translates to 'the king's power derives from his people'. The members of Bantayo Poboide functions as Ulil Amri Minkum, or the leaders among the people. During the reign of King Eyato, he defined Bantayo Poboide as a group of men without self-desire, self-interest, ambition, and regulates the government solely for the sake of public interest. The members are granted rights and capacity to supervise and control the king, as one of God's nature, kalam mutakallimun, which translates to 'free to speak without any hindrance from others'. Henceforth, the Bantayo Poboide Traditional House is constructed opposite the King's palace. Bantayo Poboide is culturally defined as Gorontalo's governmental system during the kingdom era; today, the system is preserved during special customary ceremonies. Consequently, it is a record of past government system preserved by the locals until today.

\subsection{Fort van Tangale Monument}

Fort van Tangale Monument is located at $0^{\circ} 43^{\prime} 41,77^{\prime} \mathrm{N}$ latitude and $122^{\circ} 50$ '34,9” E longitude. It is included in the administrative region of Labanu sub-district, Tibawa district, Gorontalo regency. The monument is constructed in 1922, its name is originated from a Dutchman buried in Labanu village that helped the community fight for their freedom during colonization by the Dutch. At first the monument was not much known by the locals due to 
the monument was covered by shrubs and trees nearby; moreover, near the monument, there is a nature reserve forest named Tangale Nature Reserve. The monument is one of memorial symbols of struggle for Gorontalo's independence by the locals with the help from few Dutchmen, particularly in Labanu village. The distance between the monument and Gorontalo city center is approximately 17 kilometers. Fort van Tangale monument is built to appreciate and memorize the honors of the freedom fighters, in which the names are written on the monument (Dutch people are written before the local). Beside the monument was a road that no longer exists, the road was constructed during colonial era and is no longer used, covered with trees and bushes.

\subsection{Pentadio Resort (Huntu Lo Bohu)}

The coordinate of Pentadio Resort is $00^{\circ} 36^{\prime} 56,9$ ' $\mathrm{N}$ latitude and $122^{\circ} 00^{\prime} 22,8^{\prime \prime}$ E longitude, administratively included in the region of Pentadio sub-district, Telaga Biru district, Gorontalo regency. It is one of infamous tourist attractions in Gorontalo province. Originally called libuio by the locals, the name derives from Gorontalo language word pentadu, which means lake shore, and added 'resort' meaning that it is a place to relax. The 14 hectares tourist attractions was inaugurated by the Dutch government in 1928, marked with memorial stone near the hot spring in the site. Since then, the locals utilized the hot spring as a recreational facility and to heal various diseases. Due to increasing visits from local and abroad tourists, in 2003, the government of Gorontalo regency decided to renovate and rebuild the site with more facilities to serve the visitors. There is a folk tale believed by the locals that the site is haunted by an old man. He only shows himself to people when hungry, and according to the locals, he kidnaps and eats human. He usually kidnaps non-native residents nearby the site. He is said to be able to cool off the boiling water in the resort and possess capability of healing strange diseases.

The locals argue that the old man has rarely showed himself currently. Moreover, the death rate that may be caused by the old man has been reduced compared to the past years. The old man's form is observable as three statues of man with different poses nearby a pond. The pond is located at front area of Pentadio Resort; it is noticeable right from the site's main entrance.

\subsection{Taluhu Barakati Hot Spring}

Taluhu Barakati Hot Spring is located in $00^{\circ} 32^{\prime} 32,8^{\prime \prime} \mathrm{N}$ latitude and $122^{\circ} 58^{\prime} 45,9^{\prime \prime} \mathrm{E}$ longitude. The hot spring area is included into administrative region of Barakati Village, Batudaa district, Gorontalo regency, located approximately three kilometers west from Otanaha fortress. The hot spring's name derives from two Gorontalo language words: taluhu means water, and barakati means blessings. The place is named after the site's crystal clear and refreshing spring, and two different pools with hot and cool temperature, considered as blessings from God. The spring water is said to be able heal different skin diseases. About 20 meters from the site is the sacred tomb of King Panipi, a ruler of the locals during the kingdom era of two centuries ago. Moreover, nearby the hot spring are two unique stones shaped like crocodile and pig. Lastly, Taluhu Barakati Hot Spring also have a cave named snake cave by the locals, in which it is a former excavation cave during the colonial era 
which consisted of big snakes that no longer exist by now.

\subsection{Soekarno Amphibious Aircraft Landing Monument}

Soekarno Amphibious Aircraft Landing Monument is located at coordinate of $00^{\circ} 33^{\prime} 05,8$ ' $\mathrm{N}$ latitude and $122^{\circ} 59^{\prime} 41,8^{\prime \prime} \mathrm{E}$ longitude. The monument is administratively included into region of Iluta village, Batudaa district, Gorontalo regency. Also called Dutch post, the monument of amphibious aircraft landing dock is constructed as a remembrance of honors of the first president of Republic of Indonesia. Originally functioned as a house during Dutch colonial era, the monument serves as a museum and cultural reserve of Gorontalo. It is said that the first president, Soekarno, stayed in the small house nearby the landing dock for few days. The house measures $5 \times 15$ meters and is estimated built in 1936. Moreover, the building located nearby Limboto lake shore was regarded and inaugurated by the Ministry of Cultural and Tourism Affairs cooperated with the Ancient Heritage Preservation Office of Gorontalo. Soekarno, the first president of Indonesia, landed in Gorontalo in an area nearby Limboto Lake; this lake was once called as Pantai Gorontalo. In the first visit, the president came by an amphibious aircraft. The objective of the visit is to unite all areas of Nusantara. Later in 1956, Soekarno visited Gorontalo by Catalina aircraft; the president's second visit was about the establishment of the Republic of Indonesia. This visit was also to confirm that Gorontalo would be the part of the nation as the rebellious movement was everywhere in Indonesia at the time, even a number of separatists were formed in North Sulawesi. The visit was to ensure that there was no conflict in Gorontalo despite some separatists.

\subsection{Bubohu Kingdom}

Bubohu Kingdom was once a small village or in Gorontalo called as lembo'a. This kingdom is now a village named Kampung Bongo; it is located at $00^{\circ} 29^{\prime} 57$, 4" north latitude and $122^{\circ} 02^{\prime}$ 05, 4" east latitude. The area of Bubohu Kingdom is located at Desa Bongo, Batudaa Pantai sub-district, Gorontalo regency. This small kingdom of Bubohu (linula) was first established in 1750 during the reign of nuwa (raja to tilayo) (1735-1764) and botutihe (raja tohuliyalio) (1737-1757). Bubohu is among small kingdoms within the kingdom of Hulontalo (Gorontalo). In 1750, a king of Gorontalo (Hulontalo) came to TAPA MODELO to negotiate with religious leaders, traditional authorities, and representative of the society regarding the constitution of the government and the expansion of territory. The meeting also declared that TAPA MODELO and TAPA HUOTA became one area of Gorontalo kingdom called BUBOHU with HILALUMO AMAY as its king. The area of BUBOHU kingdom covers the coastal area where its east and west borders are HULUPITO/HUNTINGO (located at Pohe sub-district, Gorontalo City) and OLIMEALA cape (this area is now a border of two sub-districts, i.e. Biluhu sub-district and Paguyaman Pantai sub-district, Boalemo regency). When Dutch colonies invaded Gorontalo, the governor-general of Dutch-Indies issued Beslit on 17 April 1889 (Staadblad no. 96 and no. 250 of 1889) considering the restructuring of the power by abolishing Bubohu kingdom and divides its area into several villages. In 1902, the center of Bubohu Kingdom became one area called Bubohu village with a village chief given the title as TI BUBOHU. 


\subsection{Baruwadi Tomb}

Baruwadi Sacred Tomb is located at $00^{\circ} 33^{\prime}$ 07, 2" north latitude and $122^{\circ} 01^{\prime}$ 02, 7" east latitude. The area of the tomb is located at Tilote village, Tabumela district, Tilango, Gorontalo regency. Gorontalo. Baruwadi was well-known as a cleric who spread the teachings of Islam in Gorontalo; he was one of the four guardians of Limboto Lake. He was famed for his spiritual ability like other clerics. According to the history, there was a person who discovers rock piles resembling a path to a mountain in Lekobalo sub-district. The path is used for people who want to visit Baruwadi tomb. However, the tomb seems to be abandoned; it is difficult to locate the tomb as many other tombs can be found in the area. Still, the base of the tomb is recognizable. There was a dome atop the base; yet, this dome now disappears. This is also the same as the gravestone of the tomb whose age is the same as the one of Jupanggola cleric; the gravestone was from 1673.

The aforementioned cultural tourism destinations tell people its history and the urban legend of the places. This also correlates with the people's culture in the past. Nowadays, such a cultural element function to inform and educate the society, as well as to preserve the local wisdom of Gorontalo by integrating the information into the local content subject.

Teaching cultural tourism to students through the local content subject is essential. This subject serves as an extracurricular activity to develop the competence of the students in terms of several aspects of local culture, i.e. the uniqueness and the advantages of the area. One of the aspects is the potential of cultural tourism in Gorontalo as it is among the efforts to develop Indonesia culture through the Act No. 5 of 2017. The content of the subject is determined by the school. Local content subject has been registered in the structure and content of the curriculum standard. This subject, which discusses the potential of cultural tourism, is the conceptualization of education that is not centralized. It is aimed at promoting the educational activities according to the situation and needs of every area. This also resonates with the effort in developing the quality of national education through the integration of local content subject in the national curriculum.

\section{Conclusion}

This study draws up several conclusions as follows:

1). Cultural tourism destinations in Gorontalo consist of Limboto Lake, Bantayo Poboide, Fort van Tangale monument, Huntu lo Bohu (Pentadio Resort), Taluhu Barakati, Soekarno Amphibious Aircraft Landing Monument, Bubohu Bongo and Baruwadi tomb history.

2). These tourism destinations function to inform the visitors regarding its history and the urban legend of the places. This also relates to the people's culture in the past. Nowadays, such a cultural element serves to inform and educate the society, as well as to preserve the local wisdom of Gorontalo by integrating the information into the local content subject.

3). It is important to teach cultural tourism to students through the local content subject. This subject serves as an extracurricular activity to shape the competence of the students regarding their local culture, i.e. the uniqueness and the advantages of the area. One of the aspects is the 
potential of cultural tourism in Gorontalo as it is among the efforts to develop Indonesia culture through the Act No. 5 of 2017.

\section{Reference}

Baruadi, M. K. (2012). Analisis Cerita Rakyat Lahilote, Kajian Struktural Semiotik. Laporan Penelitian PNBP Anggaran 2011-2012. Universitas Negeri Gorontalo

Baruadi, M. K. (2014). Pengembangan Perangkat Pembelajaran Mulok di Sekolah Dasar. Laporan Penelitian Hibah Bersaing (tahun pertama) DIKTI Tahun Anggaran 2014-2015.Universitas Negeri Gorontalo

Baruadi, M. K. (2015). Implementasi Perangkat Pembelajaran Mulok di Sekolah Dasar se Provinsi Gorontalo. Laporan Penelitian Hibah Bersaing (tahun kedua) DIKTI Tahun Anggaran 2015-2016.Universitas Negeri Gorontalo

Baruadi, M. K. (2015). Legenda Bulalo Lo Limutu. Ideas Publishing, Gorontalo

Baruadi, M. K. (2016). Pengembangan Perangkat Pembelajaran Mulok di Sekolah Menengah Pertama Berbasis Kearifan Lokal. Laporan Penelitian Hibah Bersaing (tahun pertama) RISTEKDIKTI Tahun Anggaran 2016-2017.Universitas Negeri Gorontalo

Canavan, B. (2016). Tourism culture: Nexus, characteristics, context and sustainability. Tourism Management, 53, 229-243. https://doi.org/10.1016/j.tourman.2015.10.002

Correia, A., Kozak, M., \& Ferradeira, J. (2011). Impact of Culture on Tourist Decision-making Styles. International Journal of Tourism Research, 13, 433-446. https://doi.org/10.1002/jtr.817

Danandjaja. (2005). Folklor Indonesia: Ilmu Gosip, Dongeng dan lain-lainnya. Jakarta: Graffiti

Qian, C., Sasaki, N., Shivakoti, G., \& Zhang, Y. (2016). Effective governance in tourism development - An analysis of local perception in the Huangshan mountain area. Tourism Management Perspectives, 20, 112-123. https://doi.org/10.1016/j.tmp.2016.08.003

Soekadijo, R. G. (2000). Anatomi Pariwisata Sebagai Systemic Linkage. PT. Raja Grafindo Persada, Jakarta

Vitasurya, V. R. (2015). Local Wisdom for Sustainable Development of Rural Tourism, Case on Kalibiru and Lopati Village, Province of Daerah Istimewa Yogyakarta. Social and Behavioral Sciences, 216, 97-108.

Yoeti, Oka A. (2006). Parawisata Budaya Masalah dan Solusinya. PT. Pradnya Paramita, Jakarta.

Yoeti, Oka A. (1996). Pengantar Ilmu Pariwisata. Bandung. Penerbit Angkasa.

Yulianingsih, T. (2010). Jelajah Wisata Nusantara Beragam Pilihan Tujuan Wisata di 33 Provinsi. Yogyakarta. Penerbit MedPress. 


\section{Copyright Disclaimer}

Copyright for this article is retained by the author(s), with first publication rights granted to the journal.

This is an open-access article distributed under the terms and conditions of the Creative Commons Attribution license (http://creativecommons.org/licenses/by/3.0/). 